\title{
Accumulation of heavy metals and antioxidant responses in Pinus sylvestris $L$. needles in polluted and non-polluted sites
}

\author{
Marta Kandziora-Ciupa ${ }^{1} \cdot$ Ryszard Ciepal $^{1} \cdot$ Aleksandra Nadgórska-Socha $^{1}$. \\ Gabriela Barczyk $^{1}$
}

Accepted: 28 March 2016/Published online: 31 March 2016

(C) The Author(s) 2016. This article is published with open access at Springerlink.com

\begin{abstract}
The purpose of this study was to determine the concentrations of heavy metals (cadmium, iron, manganese, lead and zinc) in current-year, 1-year old and 2-year old needles of Pinus sylvestris L. Trees were from three heavily polluted (immediate vicinity of zinc smelter, iron smelter and power plant) and three relatively clean sites (nature reserve, ecologically clean site and unprotected natural forest community) in southern Poland. Analysis also concerned the antioxidant response and contents of protein, proline, total glutathione, non-protein thiols and activity of guaiacol peroxidase (GPX) in the needles. Generally, in pine needles from the polluted sites, the concentrations of the metals were higher and increased with the age of needles, and in most cases, antioxidant responses also were elevated. The highest levels of $\mathrm{Cd}, \mathrm{Pb}$ and $\mathrm{Zn}$ were found in 2-year old pine needles collected near the polluted zinc smelter (respectively: 6.15, 256.49, $393.5 \mathrm{mg} \mathrm{kg}^{-1}$ ), $\mathrm{Fe}$ in 2-year old pine needles in the vicinity of the iron smelter $\left(206.82 \mathrm{mg} \mathrm{kg}^{-1}\right)$ and $\mathrm{Mn}$ in 2-year old needles at the ecologically clean site $\left(180.32 \mathrm{mg} \mathrm{kg}^{-1}\right)$. Positive correlations were found between $\mathrm{Fe}, \mathrm{Mn}$ and $\mathrm{Pb}$ and the content of proteins and NPTs, between $\mathrm{Cd}$ and non-protein - $\mathrm{SH}$ groups, and between $\mathrm{Zn}$ and proline levels. The activity of GPX increased under the influence of $\mathrm{Mn}$, while glutathione levels tended to decrease as Mn levels rose. The data obtained show that the levels of protein and non-protein SH groups may be useful in biological monitoring, and that
\end{abstract}

Marta Kandziora-Ciupa

marta.kandziora-ciupa@us.edu.pl

1 Department of Ecology, University of Silesia, Bankowa 9, 40-007 Katowice, Poland these ecophysiological parameters seem to be good evidence of elevated oxidative stress caused by heavy metals.

Keywords Antioxidant response $\cdot$ Heavy metal $\cdot$ Pinus sylvestris $\mathrm{L}$.
Abbreviations
NPTs Non-protein thiols
GSHt Glutathione total
GPX Guaiacol peroxidase

\section{Introduction}

Atmospheric pollution constitutes a major problem in urban environments (Al-Khlaifat and Al-Khashman 2007; Sawidis et al. 2011; Chen et al. 2016; Zhao et al. 2016). Pollutants containing trace metals are released from many different anthropogenic sources such as industry, and the combustion of fossil fuels in vehicles and energy plants (Sawidis et al. 2011). Heavy metal contamination can be exceptionally high in the vicinity of smelting operations and near mine tailings, i.e. materials left over after the process of separating the valuable fraction from the uneconomic fraction of an ore (Probst et al. 2009; Bothe 2011; Nadgórska-Socha et al. 2013b). The accumulation of those anthropogenic trace metals in plants has drawn considerable attention as a possible indicator of inorganic pollution of the environment, as plants respond directly to the state of the soil and air (Divan et al. 2009; Fowler et al. 2009; Serbula et al. 2013).

Environmental quality monitoring using biological material is commonly accepted as a reliable and affordable 
way of obtaining information on heavy metal contamination. The main advantage is the opportunity for long-term comparisons without the need for expensive equipment (Massa et al. 2010). The higher trophic plants most often used for biomonitoring in industrial and urban areas are coniferous and deciduous trees (Rademacher 2001; Piczak et al. 2003; Serbula et al. 2013). Their one great advantage is that they are long-lived, so that repeated investigations are possible over decades. They can thus be sampled systematically with standardized sampling and analytical techniques for comparative monitoring of the temporal distribution of trace elements. Trees are usually easier to identify than lower trophic plants and can be used as effective biomonitors to detect even low levels of anthropogenic pollutants. Although it can be difficult to distinguish between the amount of pollutants taken up from the soil to that deposited on the leaves, trees still reflect the cumulative effects of environmental pollution (Berlizov et al. 2007; Sawidis et al. 2011).

The Scots pine (Pinus sylvestris L.), the main forestforming species in Europe, is sensitive to several industrial pollutants, including heavy metals (Micieta and Murín 1998; Rautio et al. 1998; Nieminen et al. 2004; Chudzińska et al. 2014). Pine needles, with their thick epicuticular wax layer, are most frequently used for biomonitoring of airborne pollution due to the possibility of both passive and active uptake by tissues from the atmosphere (Mingorance et al. 2007; Sun et al. 2009, 2010; Kuang et al. 2011; Serbula et al. 2013).

Heavy metal uptake and accumulation by plant tissues causes various morphological, physiological and biochemical responses (Doganlar and Atmaca 2011). Some metal ions are likely to remain in the cytoplasm and induce oxidative stress via the generation of reactive oxygen species (ROS), which hinder cell metabolism and lead to multiple toxic effects-such as lipid peroxidation, protein cleavage or DNA damage (Pongrac et al. 2009). Plants have evolved scavenging systems that control ROS using non-enzymatic antioxidants, such as glutathione, proline, ascorbic acid, carotenoids and non-protein compound rich in - $\mathrm{SH}$ groups, as well as enzymatic anti-oxidative systems. The levels of activity of anti-oxidative enzymes such as superoxidase dismutase, glutathione peroxidase, catalase and guaiacol peroxidase (GPX) have often been examined in research on heavy metal antioxidant defenses (Pongrac et al. 2009; Kafel et al. 2010; Boojar and Tavakkoli 2010; Nadgórska-Socha et al. 2013b). Antioxidant systems in plants may be used as early indicators of environmental stress on target organisms preceding morphological or ultrastructural damage, and such as warning indicators for the ecosystem (Białońska et al. 2007). Despite the many publications on the mechanisms of plant tolerance and the role of antioxidant systems in plant adaptation to high concentrations of heavy metals, woody plants (especially conifers) have not been studied sufficiently in this area (Ivanov et al. 2012).

The objectives of the present study were to establish the concentrations of heavy metals $(\mathrm{Cd}, \mathrm{Fe}, \mathrm{Mn}, \mathrm{Pb}$ and $\mathrm{Zn})$ in the needles of $P$. sylvestris $\mathrm{L}$. growing naturally in polluted and non-polluted areas, as well as to determine and compare the levels of antioxidants (non-protein thiols, glutathione, proline), antioxidant enzyme (guaiacol peroxidase) and protein content as evidence of the measure of scavenging systems. In comparing the analytical results of heavy metals and ecophysiological changes in the pine needles, the following questions were investigated:

(a) Do the examined physiological parameters in the pine needles from the polluted sites differ from those at non-polluted sites?

(b) Are the examined physiological parameters good indicators of oxidative stress caused by heavy metals in plants living under field conditions?

\section{Materials and methods}

\section{Study area}

The study was performed in typical pine forests located in three heavily polluted sites [immediate vicinity of a zinc smelter "Miasteczko Śląskie" (M), iron smelter "ArcelorMittal Poland S.A." in Dąbrowa Górnicza-Łosień (L) and power plant "Jaworzno III" in Jaworzno (J)], and three potentially clean sites [(nature reserve "Pazurek" in Jaroszowiec Olkuski $(\mathrm{P})$, ecologically clean site "Płone Bagno" in Katowice (PB) and an unprotected natural forest community in Kobiór $(\mathrm{K})$ ]. All the sites are situated in southern parts of Poland, in either the Ślaskie or Małopolskie provinces (Fig. 1). Accurate characterization, data on soils and their contamination, and maps of the sites are given in a previous work by Kandziora-Ciupa et al. (2013).

\section{Sample collection}

The determination of heavy metal content and biochemical analyses were conducted on the needles of $P$. sylvestris $\mathrm{L}$. collected from 10 randomly chosen trees (35-40-years old) at each sampling site in mid-July of 2009. Taking into consideration individual variations in the trees, currentyear (0), 1-year old (1) and 2-year old (2) needles (about $200 \mathrm{~g}$ for each age class) were randomly sampled from branches in the upper, middle and lower crown in the eastern, southern, western and northern directions of each tree, and pooled into each age class to form a composite 


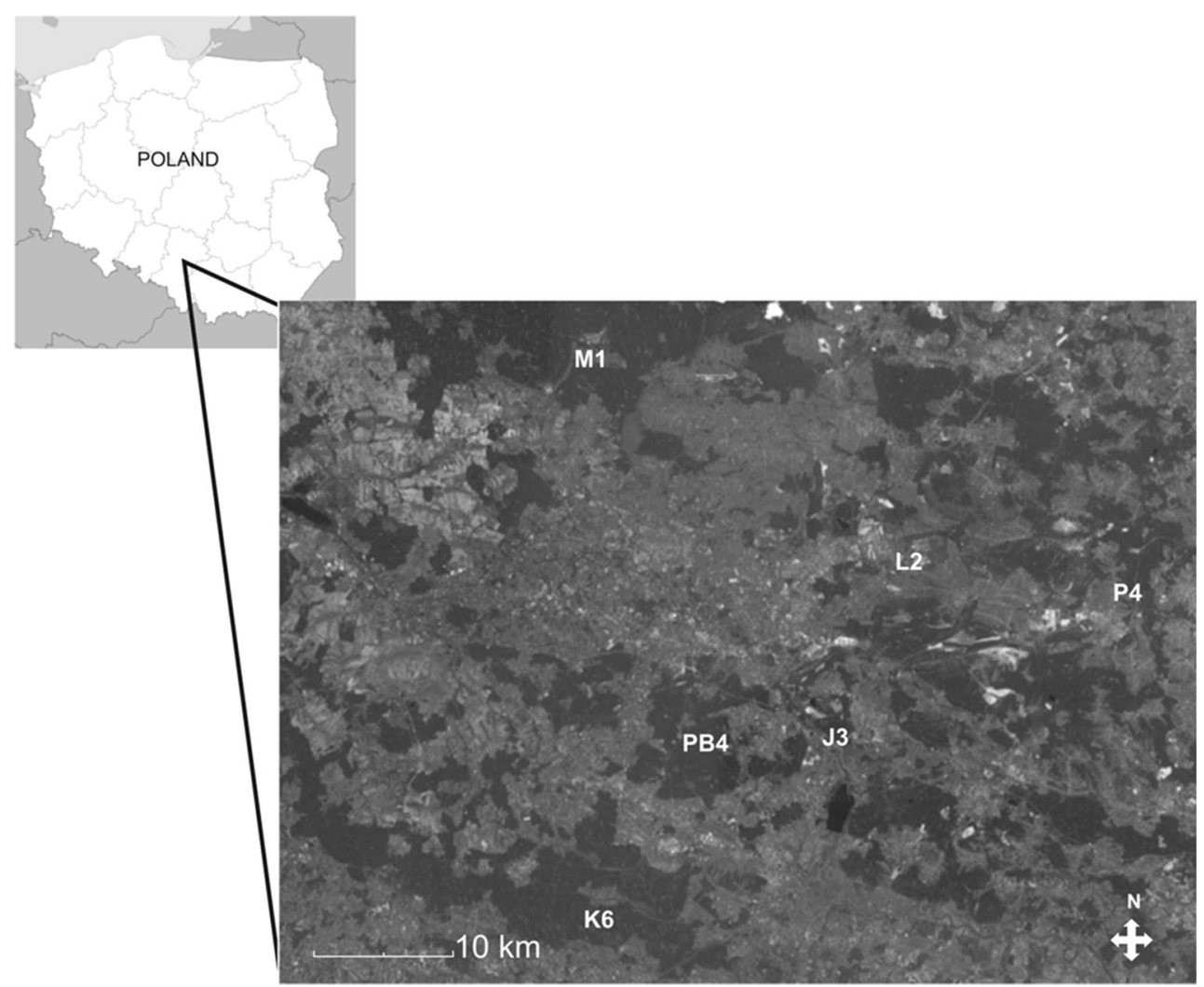

Fig. 1 Location map of sampling sites (Kandziora-Ciupa et al. 2013)

sample, thus for all analyses there were three replicates per age class per site.

After collection, samples were placed in plastic bags, deposited on ice, transported directly to the laboratory and then frozen until analysis.

\section{Analysis of metal concentrations in leaf samples}

In order to determine heavy metal concentrations in the pine needles, the plant material was washed with distilled water under a tap, and dried at $105{ }^{\circ} \mathrm{C}$. After wet mineralization (as described in detail in Kandziora-Ciupa et al. 2013), the concentrations of $\mathrm{Cd}, \mathrm{Pb}, \mathrm{Zn}, \mathrm{Fe}$ and $\mathrm{Mn}$ were established using inductively coupled plasma-atomic emission spectroscopy (Spectro Analytical Instruments). The quality of the analytical procedure was checked using a reference material (Certified reference Material CTAOTL-1 Oriental Tobacco Leaves) with the same quantities of samples.

\section{Analysis of the biochemical parameters of the plants}

Protein content was determined according to Bradford (1976) using bovine serum albumin as a standard.
Proline content was determined according to Bates et al. (1973), where $0.5 \mathrm{~g}$ of plant material was homogenized in $10 \mathrm{ml}$ of sulphosalicylic acid $(3 \mathrm{~g}$ per $100 \mathrm{ml})$, and the homogenate filtered through Whatman No. 2 filter paper. A reaction mixture containing $2 \mathrm{ml}$ of homogenate, $2 \mathrm{ml}$ ninhydrin acid and $2 \mathrm{ml}$ of glacial acetic acid was incubated at $100{ }^{\circ} \mathrm{C}$ for $1 \mathrm{~h}$. The reaction mixture was placed on ice and extracted with $4 \mathrm{ml}$ of toluene. The absorbance was read at $520 \mathrm{~nm}$ using toluene as the blank. The proline content was expressed in $\mu \mathrm{mol}$ proline per $\mathrm{g}$ fresh weight.

To measure the total glutathione concentration (GSHt), $0.5 \mathrm{~g}$ of plant parts were homogenized in TCA (trichloroacetic acid, $5 \mathrm{~g}$ per $100 \mathrm{ml}$ ) together with $0.125 \mathrm{mM}$ phosphate buffer (pH 6.3) with $6.3 \mathrm{mM}$ EDTA, and centrifuged at $10,000 \mathrm{~g}$ for $10 \mathrm{~min}$ at $4{ }^{\circ} \mathrm{C}$. Supernatants were used for GSH determination using the DTNB-GSSG reductase recycling procedure according to Anderson (1985). The reaction mixture contained $0.2 \mathrm{ml}$ of supernatant, $0.6 \mathrm{ml}$ of $0.3 \mathrm{mM}$ NADPH, $0.1 \mathrm{ml}$ of $6 \mathrm{mM}$ DTNB and $0.1 \mathrm{ml}\left(0.5 \mathrm{IU} \mathrm{m}^{-1}\right)$ of glutathione reductase. The linear changes in the absorbance of the reaction mixtures were measured at $412 \mathrm{~nm}$ and the GSHt was expressed as $\mu \mathrm{mol} \mathrm{GSH} \mathrm{g}{ }^{-1}$ fresh weight.

The content of non-protein thiols was estimated per the method described by Mass et al. (1987), where plant 
material was homogenized in a $5 \mathrm{vol} \mathrm{g}^{-1}$ mixture containing 5-sulphosalicylic acid $(2 \mathrm{~g}$ per $100 \mathrm{ml}), 1 \mathrm{mM}$ EDTA and sodium ascorbate $(0.15 \mathrm{~g}$ per $100 \mathrm{ml})$. The samples were centrifuged at $20,000 \mathrm{~g}$ for $10 \mathrm{~min}$ at $4{ }^{\circ} \mathrm{C}$. Following this, $0.5 \mathrm{ml}$ of liquid supernatant, $0.5 \mathrm{ml}$ of $1 \mathrm{M}$ sodium phosphate buffer (pH 8.0) and $100 \mu \mathrm{l}$ of $10 \mathrm{mM}$ 5,5'-dithio-bis (2-nitrobenzoic acid) (DTNB) were put into the test tubes. The absorbance at $415 \mathrm{~nm}$ was read $1 \mathrm{~min}$ after the addition of DTNB. The number of non-protein SH groups was established based on a curve prepared using Lcysteine and was expressed in nmol $-\mathrm{SH} \mathrm{g}^{-1}$ fresh weight.

For the analysis of guaiacol peroxidase fresh plant material was homogenized in a $100 \mathrm{mM}$ phosphate buffer (pH 6.8). GPX activity was measured at $470 \mathrm{~nm}$ according to Fang and Kao (2000) and Liu et al. (2004) with guaiacol as the substrate. GPX activity was measured in a reaction mixture $(3 \mathrm{ml})$ containing $50 \mathrm{mM}$ phosphate buffer $(\mathrm{pH}$ 5.8), $1.6 \mu \mathrm{l} \mathrm{H}_{2} \mathrm{O}_{2}, 1.5 \mu \mathrm{l}$ guaiacol and $0.2 \mathrm{ml}$ enzyme extract. Activity was calculated using the extinction coefficient $\left(26 \mathrm{mM}^{-1} \mathrm{~cm}^{-1}\right)$ for tetraguaiacol and was expressed in $\mu \mathrm{mol}$ tetra-guaiacol $\mathrm{g}^{-1}$ fresh weight $\min ^{-1}$.

\section{Statistical analysis}

Data concerning the biochemical parameters and metal content were analysed $(n=3)$, checked for normality and equality of variance. The data was analyzed by ANOVA and the treatments were treated as independent variables. Significant statistical differences for all variables were established using Tukey tests, $p<0.05$ (ANOVA; Statistica 10 package). We also calculated the Pearson correlation coefficient between the metal concentrations and biochemical parameters of the pine needles. Multiple regression equations were derived to determine which of the investigated metals influenced antioxidant levels and peroxidase activity in the needle samples from the study areas. The method of stepwise forward regression was applied. The equations concerned the the relationships between peroxidase (GPX) activity, the levels of glutathione (GSHt), non-protein thiols (NPTs), proline as well as protein, and the examined accumulated metals in the needles $(\mathrm{Zn}, \mathrm{Pb}, \mathrm{Cd}, \mathrm{Mn}, \mathrm{Fe})$. Significance of differences was set at a level of $p<0.05$.

\section{Results}

\section{Heavy metal concentrations in $P$. sylvestris needles}

The mean values of heavy metal concentrations found in the $P$. sylvestris needles were placed in the following descending order: $\mathrm{Mn}>\mathrm{Zn}>\mathrm{Fe}>\mathrm{Pb}>\mathrm{Cd}$. There was a clear increase in the concentrations of the studied metals in the $P$. sylvestris needles from the polluted sites. The exception to this was $\mathrm{Mn}$, where the highest levels were observed at the three non-polluted sites P, PB and K. Metal content in $P$. sylvestris needles also increased with increasing needle age class (Table 1). The highest $\mathrm{Cd}, \mathrm{Pb}$ and $\mathrm{Zn}$ concentrations (respectively: 6.15, 256.49, $393.5 \mathrm{mg} \mathrm{kg}^{-1}$ ) were found in 2-year old pine needles collected at site $\mathrm{M}$, the highest $\mathrm{Fe}$ content (206.82 $\mathrm{mg} \mathrm{kg}^{-1}$ ) in 2-year old pine needles at site $\mathrm{L}$, and Mn (180.32 $\mathrm{mg} \mathrm{kg}^{-1}$ ) content highest in 2-year old pine needles from the non-polluted site PB (Table 1).

\section{Biochemical status of the plants}

The highest content of proteins (1.12 $\mathrm{mg} \mathrm{g}^{-1}$ fresh weight) (Fig. 2), proline (Fig. 3) and non-protein -SH (481 nmol $\mathrm{SH} \mathrm{g}{ }^{-1}$ fresh weight) (Fig. 5) groups were found in $P$. sylvestris needles collected from the contaminated areas (M) in comparison to the potentially clean sites. The highest accumulation of GSHt was found in P. sylvestris needles from the site $\mathrm{L}-28.89 \mu \mathrm{mol}$ GSHt $\mathrm{g}^{-1}$ fresh weight (Fig. 4). There were no clear differences in glutathione content between the polluted and non-polluted sites (Fig. 4). Guaiacol peroxidase activity was by far highest in the pine needles from the non-polluted site $\mathrm{K}$ (8.04-13.66 $\mu$ mol tetra-guaiacol $\mathrm{g}^{-1}$ fresh weight $\min ^{-1}$ ), where there were also high $\mathrm{Mn}$ concentrations (Fig. 6; Table 1).

The high multiple corrected correlation coefficients for the values presented in Table 2 suggest that the models (except GSHt) describe the majority of the variations for each dependent variable (antioxidants and GPX). Fe, Mn and $\mathrm{Pb}$ had a positive influence on protein content and NPTs (additionally, we found a positive correlation between non-protein - $\mathrm{SH}$ groups and $\mathrm{Cd}$ content in pine needles). Moreover, a positive correlation occurred between Mn contents and GPX as well as $\mathrm{Zn}$ concentration and proline content in the needles (Table 2). Only Mn had a negative effect on GSHt. These results are supported by the positive Pearson's correlation coefficient values obtained between the examined antioxidants and GPX and the above mentioned metals (Table 3).

In most cases (except GSHt concentration) there was an age-related increase in content or activity of investigated biochemical parameters. The total glutathione pool was mostly lower in the older pine needles.

\section{Discussion}

The accumulation of heavy metals in forest vegetation is highly variable and affected by both physiological and environmental factors. Bioaccumulation of heavy metals 
Table 1 The concentrations of heavy metals $\left(\mathrm{mg} \mathrm{kg}^{-1} \mathrm{dw}\right.$ ) in the needles of $P$. sylvestris (mean values $\pm \mathrm{SE}, \mathrm{n}=3$ )

\begin{tabular}{|c|c|c|c|c|c|c|}
\hline Site & Needles age class & $\mathrm{Cd}$ & $\mathrm{Fe}$ & $\mathrm{Mn}$ & $\mathrm{Pb}$ & $\mathrm{Zn}$ \\
\hline \multirow[t]{3}{*}{ M } & M0 & $1.89 \pm 0.01 \mathrm{c}$ & $49.39 \pm 1.33 \mathrm{c}$ & $59.22 \pm 0.20 \mathrm{~b}$ & $31.23 \pm 1.13 \mathrm{~d}$ & $121.70 \pm 5.03 \mathrm{c}$ \\
\hline & M1 & $4.39 \pm 0.05 \mathrm{c}$ & $86.90 \pm 1.02 \mathrm{~d}$ & $67.07 \pm 3.82 \mathrm{~b}$ & $212.99 \pm 5.50 \mathrm{c}$ & $290.50 \pm 1.83 \mathrm{f}$ \\
\hline & M2 & $6.15 \pm 0.24 \mathrm{~b}$ & $143.25 \pm 0.77 \mathrm{~d}$ & $77.31 \pm 3.05 \mathrm{a}$ & $256.49 \pm 2.00 \mathrm{c}$ & $393.50 \pm 1.50 \mathrm{f}$ \\
\hline \multirow[t]{3}{*}{$\mathrm{L}$} & L0 & $0.02 \pm 0.00 \mathrm{a}$ & $51.29 \pm 8.37 \mathrm{c}$ & $23.82 \pm 4.57 \mathrm{a}$ & $5.98 \pm 0.30 \mathrm{~b}$ & $35.13 \pm 3.30 \mathrm{~b}$ \\
\hline & $\mathrm{L} 1$ & $0.17 \pm 0.00 \mathrm{~b}$ & $197.82 \pm 0.67 \mathrm{f}$ & $39.77 \pm 2.82 \mathrm{a}$ & $10.38 \pm 0.94 \mathrm{ab}$ & $79.47 \pm 0.03 \mathrm{e}$ \\
\hline & L2 & $0.17 \pm 0.00 \mathrm{a}$ & $206.82 \pm 2.33 \mathrm{e}$ & $62.07 \pm 1.68 \mathrm{a}$ & $15.76 \pm 0.30 \mathrm{~b}$ & $142.87 \pm 2.20 \mathrm{e}$ \\
\hline \multirow[t]{3}{*}{$\mathrm{J}$} & J0 & $0.03 \pm 0.01 \mathrm{a}$ & $29.60 \pm 1.38 \mathrm{ab}$ & $76.96 \pm 3.87 \mathrm{c}$ & $7.64 \pm 0.72 \mathrm{bc}$ & $38.30 \pm 3.67 \mathrm{~b}$ \\
\hline & $\mathrm{J} 1$ & $0.09 \pm 0.02 \mathrm{a}$ & $72.24 \pm 0.72 \mathrm{c}$ & $92.56 \pm 1.87 \mathrm{c}$ & $14.83 \pm 0.15 \mathrm{~b}$ & $68.40 \pm 1.00 \mathrm{~d}$ \\
\hline & $\mathrm{J} 2$ & $0.15 \pm 0.05 \mathrm{a}$ & $97.97 \pm 12.05 b$ & $127.21 \pm 19.98 b$ & $13.66 \pm 1.51 \mathrm{~b}$ & $113.37 \pm 7.87 \mathrm{~d}$ \\
\hline \multirow[t]{3}{*}{$\mathrm{P}$} & $\mathrm{P} 0$ & $0.10 \pm 0.07 \mathrm{ab}$ & $59.29 \pm 1.93 \mathrm{c}$ & $80.94 \pm 7.62 \mathrm{c}$ & $8.70 \pm 0.15 \mathrm{c}$ & $43.30 \pm 0.13 \mathrm{~b}$ \\
\hline & $\mathrm{P} 1$ & $0.15 \pm 0.02 \mathrm{ab}$ & $62.00 \pm 0.88 \mathrm{~b}$ & $132.02 \pm 9.07 \mathrm{~d}$ & $13.00 \pm 1.78 \mathrm{~b}$ & $61.00 \pm 1.87 \mathrm{c}$ \\
\hline & $\mathrm{P} 2$ & $0.22 \pm 0.02 \mathrm{a}$ & $114.95 \pm 0.73 \mathrm{c}$ & $173.47 \pm 17.18 \mathrm{c}$ & $16.51 \pm 0.15 \mathrm{~b}$ & $75.35 \pm 0.68 \mathrm{c}$ \\
\hline \multirow[t]{3}{*}{$\mathrm{PB}$} & PB0 & $0.07 \pm 0.04 \mathrm{a}$ & $35.12 \pm 3.17 \mathrm{~b}$ & $84.86 \pm 3.90 \mathrm{c}$ & $3.23 \pm 0.02 \mathrm{a}$ & $21.00 \pm 3.00 \mathrm{~b}$ \\
\hline & PB1 & $0.08 \pm 0.04 \mathrm{a}$ & $89.95 \pm 0.43 \mathrm{e}$ & $159.51 \pm 2.92 \mathrm{e}$ & $6.03 \pm 0.35 \mathrm{a}$ & $55.05 \pm 0.85 \mathrm{~b}$ \\
\hline & PB2 & $0.18 \pm 0.02 \mathrm{a}$ & $87.67 \pm 1.68 b$ & $180.32 \pm 11.33 \mathrm{c}$ & $6.87 \pm 1.68 \mathrm{a}$ & $61.43 \pm 0.03 \mathrm{~b}$ \\
\hline \multirow[t]{3}{*}{$\mathrm{K}$} & K0 & $0.18 \pm 0.03 \mathrm{~b}$ & $19.54 \pm 0.65 \mathrm{a}$ & $58.57 \pm 0.92 \mathrm{~b}$ & $2.35 \pm 0.62 \mathrm{a}$ & $12.11 \pm 0.47 \mathrm{a}$ \\
\hline & $\mathrm{K} 1$ & $0.21 \pm 0.01 \mathrm{~b}$ & $47.42 \pm 0.00 \mathrm{a}$ & $137.54 \pm 3.82 \mathrm{e}$ & $4.25 \pm 0.05 \mathrm{a}$ & $17.30 \pm 0.20 \mathrm{a}$ \\
\hline & $\mathrm{K} 2$ & $0.37 \pm 0.00 \mathrm{a}$ & $63.92 \pm 0.00 \mathrm{a}$ & $167.56 \pm 7.10 \mathrm{c}$ & $5.17 \pm 0.02 \mathrm{a}$ & $19.18 \pm 0.12 \mathrm{a}$ \\
\hline Sufficient or Normal ${ }^{\mathrm{a}}$ & - & $0.05-0.2$ & - & $30-300$ & $5-10$ & $27-150$ \\
\hline Excessive or Toxic ${ }^{\mathrm{a}}$ & - & $5-30$ & - & $400-1000$ & $30-300$ & $100-400$ \\
\hline
\end{tabular}

The different letters denote significant differences between the particular metal concentrations in the same needles age class $(p<0.05)$

a According to Kabata-Pendias and Pendias (2001)

Fig. 2 Protein contents $\left(\mathrm{mg} \mathrm{g}^{-1}\right.$ fresh weight) in $P$. sylvestris needles (mean values $\pm \mathrm{SE}, \mathrm{n}=3$ ). Different letters above the columns indicate significant differences in the same needles age class $(p<0.05)$

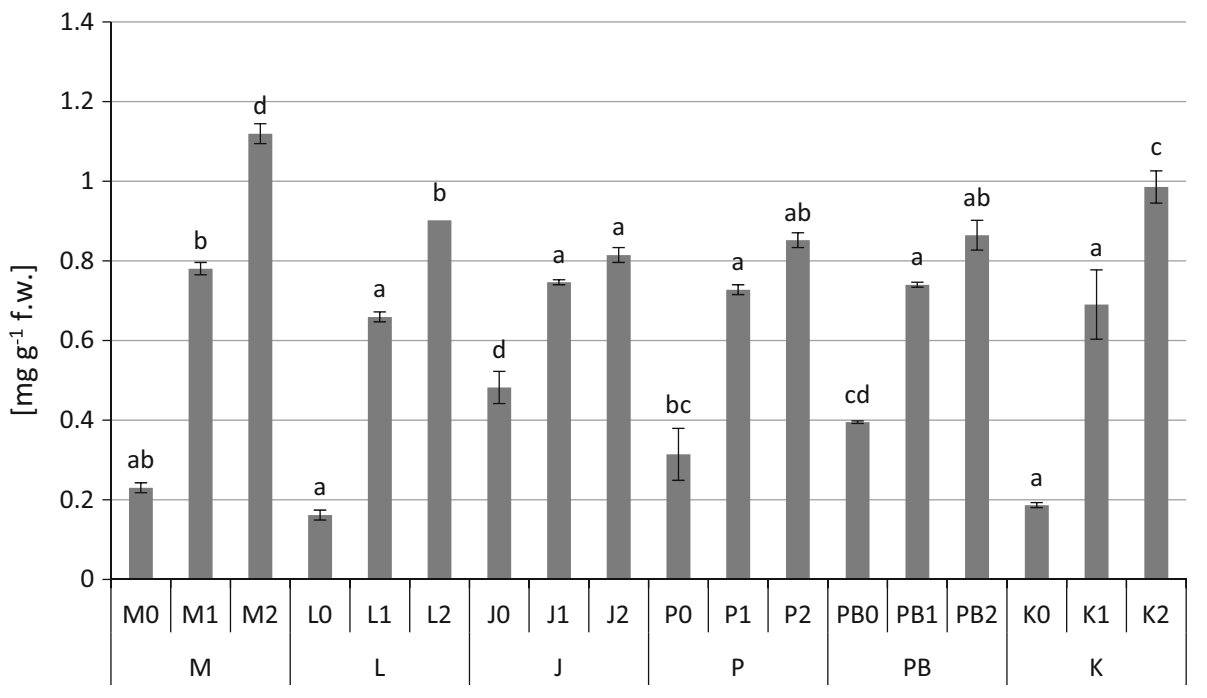

by plant foliage presents a health risk to wildlife and potentially to humans (Pacyna and Pacyna 2001; KabataPendias and Pendias (2001); McGee et al. 2007). Higher plants are believed to be less tolerant to increased concentrations of heavy metals, and to accumulate these elements and survive in highly heavy metal contaminated soils. The most toxic metals for higher plants in high concentrations in tissues include $\mathrm{Pb}$ and $\mathrm{Cd}$ (Ots and Mandre 2012).

Significantly higher levels of $\mathrm{Cd}, \mathrm{Pb}$ and $\mathrm{Zn}$ were found in the pine needles collected at the site located near a zinc smelter (M), in comparison with all the other sites (Table 1). The levels of these three metals exceeded values considered as normal (according to Kabata-Pendias and 
Fig. 3 Proline contents ( $\mu \mathrm{mol} \mathrm{g}^{-1}$ fresh weight) in $P$. sylvestris needles (mean values $\pm \mathrm{SE}, \mathrm{n}=3$ ). Different letters above the columns indicate same needles age class $(p<0.05)$

Fig. 4 Total glutathione contents ( $\mu$ mol GSHt ${ }^{-1}$ fresh weight) in $P$. sylvestris needles (mean values $\pm \mathrm{SE}, \mathrm{n}=3$ ). Different letters above the columns indicate significant age class $(p<0.05)$ significant differences in the differences in the same needles
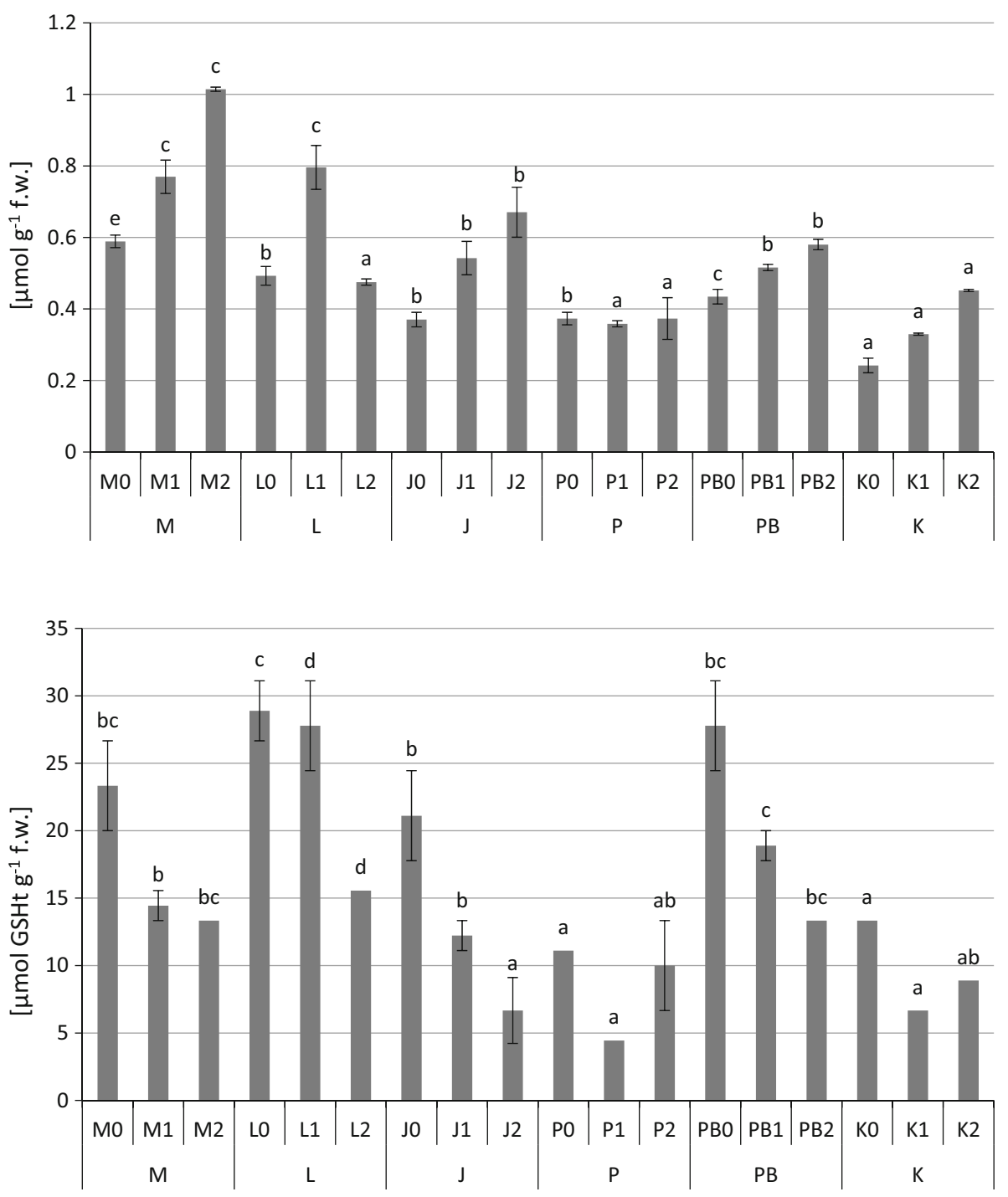

Table 2 Multiple regression equations $(p<0.05)$

\begin{tabular}{ll}
\hline & $\mathrm{R}^{2}$ \\
\hline Protein $=-0.061+0.539(\mathrm{Fe})+0.691(\mathrm{Mn})+0.416(\mathrm{~Pb})$ & 0.863 \\
Proline $=0.38+0.817(\mathrm{Zn})$ & 0.646 \\
$\mathrm{GSHt}=25.06-0.62(\mathrm{Mn})$ & 0.339 \\
NPTs $=-10.899+0.96(\mathrm{Cd})+0.598(\mathrm{Fe})+0.597(\mathrm{Mn})+1.35(\mathrm{~Pb})$ & 0.929 \\
GPX $=0.80+0.866(\mathrm{Mn})$ & 0.750 \\
\hline
\end{tabular}

Pendias 2001) and rose with the increasing age class of the pine needles. A similar pattern was observed by examining the contents of heavy metals in the leaves of Vaccinium myrtillus L. growing at the same sites (Kandziora-Ciupa et al. 2013). Also Chudzińska et al. (2014) examined 1-year-old $P$. sylvestris needles from the vicinity of the same zinc smelter in Miasteczko Ślaskie and determined similar amounts of $\mathrm{Cd}, \mathrm{Pb}$ and $\mathrm{Zn}$ to our investigations. At the non-polluted sites, the concentrations of $\mathrm{Cd}, \mathrm{Pb}, \mathrm{Zn}, \mathrm{Fe}$ and Mn were similar to other non-polluted sites reported in literature (Parzych and Sobisz 2012; Serbula et al. 2013).

One of the mechanisms in plants affected by heavy metals is protein synthesis. It is known that soluble protein content is an important indicator of the physiological status of the plant (Doganlar and Atmaca 2011). In this study we noticed an increase in protein content in pine needles from polluted sites, especially in 1-year old and 2-year old needles (Fig. 2), and a positive correlation between Fe, Mn 
Table 3 The correlation coefficients between metal concentration and antioxidant measurements in the in the needles of $P$. sylvestris $(p<0.05)$

\begin{tabular}{lllclc}
\hline & $\mathrm{Cd}$ & $\mathrm{Fe}$ & $\mathrm{Mn}$ & $\mathrm{Pb}$ & $\mathrm{Zn}$ \\
\hline Protein & 0.34 & 0.57 & 0.54 & 0.40 & 0.47 \\
Proline & 0.73 & 0.55 & $\mathrm{NS}$ & 0.73 & 0.81 \\
GSHt & NS & NS & -0.59 & NS & NS \\
NPTs & 0.34 & 0.67 & 0.45 & 0.42 & 0.52 \\
GPX & NS & NS & 0.85 & NS & -0.27 \\
\hline
\end{tabular}

$N S$ not significant

and $\mathrm{Pb}$ (Tab. 2). In a previous work, we found a strong positive correlation between protein content and $\mathrm{Cd}, \mathrm{Pb}$ and $\mathrm{Zn}$ concentrations in the leaves of $V$. myrtillus (Kandziora-Ciupa et al. 2013). Also Doganlar and Atmaca (2011) reported an increase in total soluble protein content related to $\mathrm{Al}$ concentration in the leaves of $P$. orientalis, and $\mathrm{Zn}$ concentration in the leaves of M. azaderach. Mesmar and Jaber (1991) found an increase in total protein content related to an increase in lead concentration in wheat and lentil, and Singh et al. (2006) reported increased protein content in Oryza sativa under $\mathrm{Cd}$ stress. This increase may be a specific mechanism by which cells compensate for the protein content that has been deactivated due to metal binding, and also the effect of the increasing content of stress proteins (Mesmar and Jaber 1991; Seregin and Ivanov 2001).

Enzymatic and non-enzymatic antioxidants are important in plant defenses against heavy metals (Gill and Tuteja 2010). Moreover a field study concerning activity of oxidative enzymes may be helpful in evaluating these as biomarkers in the future, and may also help in understanding the defense mechanism of plants under chronic heavy metal stress (Nadgórska-Socha et al. 2013b).

Low molecular compounds, such as proline, play an important role in cell protection against ROS-induced damage (Kartashov et al. 2008; Ivanov et al. 2013). Metalinduced proline accumulation has been observed, and it has been suggested that this amino acid acts as a radical scavenger or it is involved in metal ion chelation (Andrade et al. 2009). In plants, proline constitutes $<5 \%$ of the total pool of free amino acids under normal conditions and $80 \%$ of the total amino acid pool under stress (Kumar et al. 2010). An increase in proline levels in response to the impact of heavy metals is a widespread phenomenon among many plant species and has been noted by many investigators (Schat et al. 1997, Chen et al. 2004; Tripathi and Gaur 2004; Balestrasse et al. 2005; Sharma and Dietz 2006; Sun et al. 2007; Abdel-Latif 2008).

Our tests found a significant effect of $\mathrm{Zn}$ on the accumulation of proline in the needles of $P$. sylvestris (Table 2).
The highest proline content was observed in pine needles in the vicinity of the zinc smelter (site $\mathrm{M}$ ) and the iron smelter (site L) (Fig. 3). An increase in free proline level during environmental contamination was also found in Philadelphus coronarius leaves (Kafel et al. 2010). Ivanov et al. (2012) demonstrated a significant proline accumulation in the roots, hypocotyls and needles of Scots pine seedlings in response to the action of $150 \mu \mathrm{M} \mathrm{Pb}^{2+}$, and in the needles, cotyleodons and stems at $150 \mu \mathrm{M} Z \mathrm{Zn}$. Nikolić et al. (2008) found a significantly higher accumulation of free proline in the roots than the leaves of hybrid poplar under the influence of Cd. Zengin and Munzuroglu (2005) registered a significant increase of proline content in bean leaves treated with $\mathrm{Pb}, \mathrm{Cu}, \mathrm{Cd}$ and $\mathrm{Hg}$. Sharma and Dietz (2006) reported an increase in free proline accumulation in response to the increased accumulation of heavy metals in several examples of flowering plants.

Glutathione is a very important low molecular weight biological thiol crucial for the detoxification of heavy metals; which also acts as a precursor for the synthesis of phytochelatins (Yadav 2010). GSH creates complexes with heavy metals, and an induction of glutathione has been documented in plants as a response to heavy metal stress. The changes in GSHt level are dependent on the metal and the part of the plant (Arya et al. 2008; Nadgórska-Socha et al. 2013a).

As in previous research (Kandziora-Ciupa et al. 2013) on bilberry leaves, we found a decline in GSHt due to increased concentrations of Mn (Table 2). We observed a decrease in glutathione with increasing age class of the pine needles, also we found a negative correlation coefficient between the content of $\mathrm{Mn}$ and GSHt which was confirmed by the regression equation (Fig. 4; Tables 2, 3). In many cases, exposure to heavy metals results in reduced glutathione levels ( $\mathrm{Ni}$ and $\mathrm{Zn}$ in Cajanus cajan-Madhava Rao and Sresty 2000; Cd in pine-Schützendübel et al. 2001; Pb in Vicia faba and Phaseolus vulgaris-Piechalak et al. 2002; Cd in Triticum aestivum L.-_Lin et al. 2007; $\mathrm{Cd}$ in young Picea omorika (Pančić) Purk.-Dučić et al. 2008; Pb in Raphanus sativus-El-Beltagi and Mohamed 2010). This decline in the glutathione content in plants may result from inhibition of the enzymes involved in glutathione synthesis by toxic metal ions. In addition, the reduction in glutathione pool may also be considered to play some role in the synthesis of phytochelatins (PCs) (Madhava Rao and Sresty 2000). Sudhakar et al. (2006) showed that exposure of Hydrilla verticillata (L.f.) Royle to high doses of copper led to a decrease in GSH as a result of increased phytochelatin synthesis. Boojar and Tavakkoli (2010) found a similar dependency in Alhagi camemelorum. Fisch and de Vos et al. (1992) also indicated a decrease in GSHt caused by $\mathrm{Cu}$ in Silene cucubalus and an elevation in PC levels. 
In plant cells, low-molecular weight compounds other than glutathione containing - SH groups can exist, such as phytochelatins, metallothioneins, thionins and defensins (Nadgórska-Socha et al. 2013b). Molecules containing sulphur, which exist in a wide variety of cells, may fulfill different functions and may be independently regulated (Mishra et al. 2009). Non-protein compounds rich in -SH groups are involved in metal detoxification and/or metal allocation between different organs of the plant, because their main task is binding of metal ions and forming nontoxic complexes with metals which are transported from the cytoplasm into the vacuole (Andrade et al. 2010; Yadav 2010).

In our study, an increase in NPT content was noticed in the needles of $P$. sylvestris grown at the most polluted sites ( $\mathrm{M}$ and L), especially in the 2-year old needles, and also at clean sites where we noted high concentrations of $\mathrm{Mn}$ (Fig. 5). Additionally, the content of non-protein thiols was positively related with concentrations of $\mathrm{Cd}, \mathrm{Fe}, \mathrm{Mn}$ and $\mathrm{Pb}$ (Table 2). Our results were similar to Nadgórska-Socha et al. (2011) who observed an increase in non-protein -SH group content in the leaves of Silene vulgaris populations on a substrate with $\mathrm{Cd}$ and a combination of metals ( $\mathrm{Zn}, \mathrm{Cd}$ and Pb). Also Mishra et al. (2009) and Pongrac et al. (2009) found a strong positive correlation between NPT and Cd content in Ceratophyllum demersum L. and Thlapsi praeox. The increase in non-protein thiol levels indicates an ability to tolerate the cellular metal load (Mishra et al. 2006).

Peroxidases are antioxidant enzymes which are significant in plant growth and development. Activities of these enzymes are changed under both biotic and abiotic stress conditions, and so are used as a potential indicator of metal toxicity (Radotić et al. 2000; Macfarlane and Burchett 2001; Baycu et al. 2006; Doganlar and Atmaca 2011;
Kandziora-Ciupa et al. 2013). For example, in Radotić et al. (2000), peroxidases were used as a potential biomarker for sublethal toxicity in spruce seedlings.

In this study on pine needles, the highest GPX activity was observed at the clean sites, where we also detected the highest content of $\mathrm{Mn}$. The lowest values of guaiacol peroxidase activity were observed at the polluted sites $\mathrm{M}$ and L (Fig. 6). An increase in GPX activity in P. sylvestris needles was observed under the influence of higher levels of Mn (Table 2).

Many authors have reported increasing GPX activity with increasing heavy metal content (Macfarlane and Burchett 2001; Markkola et al. 2002, Hagemeyer 2004; Nadgórska-Socha et al. 2008; Kafel et al. 2010; El-Beltagi and Mohamed 2010; Doganlar and Atmaca 2011; Nadgórska-Socha et al. 2013a, b). However, similar to our work, Baycu et al. (2006), in their examination of peroxidase activity in the leaves of deciduous trees growing in urban parks in Turkey, also observed both increased and decreased peroxidase activity. Sometimes chronic metalinduced stress did not cause a measurable increase in oxidative stress (Słomka et al. 2008). Results obtained by Pongrac et al. (2009) reported no change in GPX activity in Thalspsi praecox and T. caerulescens in the presence of $\mathrm{Cd}$ and $\mathrm{Zn}$; similar results were observed by Gratão et al. (2008) in the leaves, roots and fruits of the tomato grown in conditions of cadmium contamination. Słomka et al. (2008) demonstrated comparable or lower activity of peroxidase in the leaves of Viola tricolor in metalliferous versus clean areas. Sandalio et al. (2001) noticed a decrease in peroxidase activity in pea plants under the influence of Cd. Stress intensity may be linked to an increase or decrease in oxidative metabolism. The modulation of antioxidant levels constitutes an important adaptive response in
Fig. 5 Non-protein -SH groups content (nmol $-\mathrm{SH} \mathrm{g}^{-1}$ fresh weight) in $P$. sylvestris needles (mean values $\pm \mathrm{SE}, \mathrm{n}=3$ ). Different letters above the columns indicate significant differences in the same needles age class $(p<0.05)$

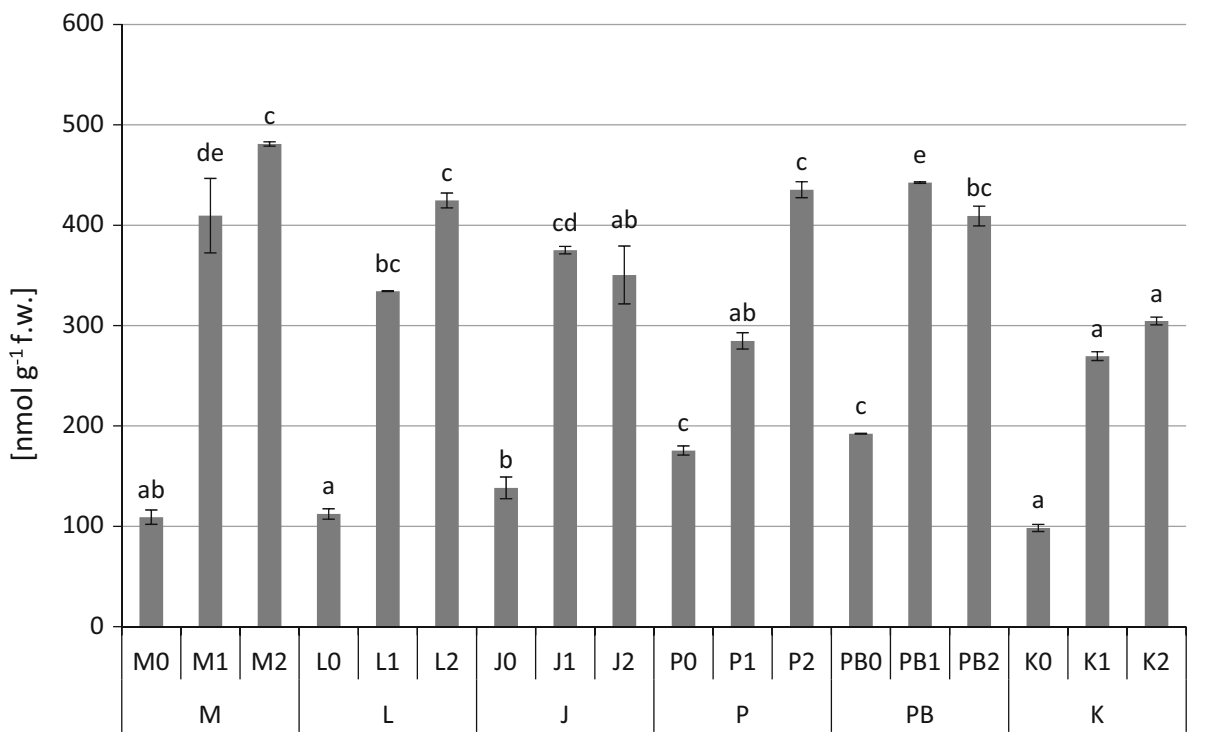


Fig. 6 Guaiacol peroxidase activity ( $\mu$ mol tetra-guaiacol $\mathrm{g}^{-1}$ fresh weight $\left.\mathrm{min}^{-1}\right)$ in $P$. sylvestris needles (mean values $\pm \mathrm{SE}, \mathrm{n}=3$ ). Different letters above the columns indicate significant differences in the same needles age class $(p<0.05)$

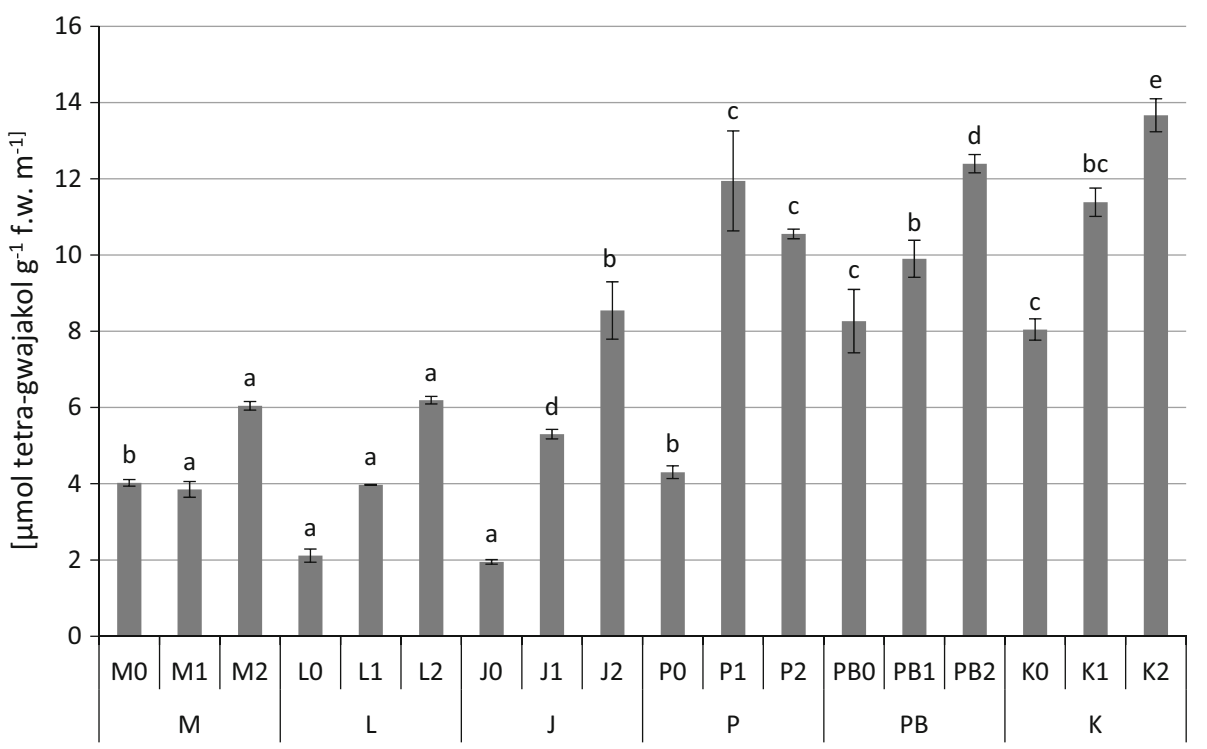

withstanding adverse conditions, and maintenance of a high antioxidant capacity in cells is linked to increased tolerance against stress, for instance to heavy metal contamination (Thomas et al. 1999, Baycu et al. 2006). For this reason, varying antioxidative enzyme activity in response to heavy metals has often been found (Baycu et al. 2006).

It is difficult to draw clear major conclusions from research carried out in the wild, and we do realize that the examined ecophysiological parameters are influenced by many factors, and that it is not possible to take them all into account during in situ studies. Nevertheless a multiparametic approach provides an understanding of the diverse responses and effects of exposure to contaminants, and the effective risks posed for different plant species (Stobrawa and Lorenc-Plucińska 2007; Fonseca et al. 2011; Oliva et al. 2012; Kandziora-Ciupa et al. 2013).

Based on our study we can conclude that: an increase in content of protein and non-protein - $\mathrm{SH}$ groups in the needles of $P$. sylvestris from polluted sites is most likely evidence of enhanced oxidative stress caused by heavy metals. Therefore, these ecophysiological parameters seem to be good biochemical markers to predict heavy metal pollution.

Acknowledgments This work was financially supported by the Polish State Committee for Scientific Research, Project No. N N304 378938 .

\section{Compliance with ethical standards}

Conflict of interest The authors declare that they have no conflict of interest.

Informed consent Informed consent was obtained from all individual participants included in the study.
Open Access This article is distributed under the terms of the Creative Commons Attribution 4.0 International License (http://creative commons.org/licenses/by/4.0/), which permits unrestricted use, distribution, and reproduction in any medium, provided you give appropriate credit to the original author(s) and the source, provide a link to the Creative Commons license, and indicate if changes were made.

\section{References}

Abdel-Latif A (2008) Cadmium induced changes in pigment content, ion uptake, proline content and phosphoenolpyruvate carboxylase activity in Triticum Aestivum seedlings. Aust J Basic Appl Sci 2(1):57-62

Al-Khlaifat A, Al-Khashman O (2007) Atmospheric heavy metal pollution in Aqaba city, Jordan, using Phoenix dactylifera L. leaves. Atmos Environ 41:8891-8897

Anderson ME (1985) Determination of glutathione and glutathione disulfide in biological samples. Methods Enzymol 113:548-555

Andrade SAL, Gratão PL, Azevedo RA, Silveira APD, Schiavinato MA, Mazzafera P (2010) Biochemical and physiological changes in Jack bean under mycorrhizal symbiosis growing in soil with increasing $\mathrm{Cu}$ concentrations. Environ Exp Bot 68:198-207

Andrade SAL, Gratão PL, Schiavinato MA, Silveira AP, Azevedo RA, Mazzafera P (2009) Zn uptake, physiological response and stress attenuation in mycorrhizal jack bean growing in soil with increasing Zn concentrations. Chemosphere 75:1363-1370

Arya SK, Khalique S, Roy BK (2008) Glutathione and cysteine biosynthesis in two varieties of Abelmoschus esculentus in response to mine spoil. J Environ Biol 29(1):93-99

Balestrasse KB, Gallego SM, Benavides MP, Tomaro ML (2005) Polyamines and proline are affected by cadmium stress in nodules and roots of soybean plants. Plant Soil 270:343-353

Bates L, Waldren R, Teare D (1973) Rapid determination of free proline for water-stress studies. Plant Soil 39:205-207

Baycu G, Tolunay D, Özden H, Guenenebakan S (2006) Ecophysiological and seasonal variations in $\mathrm{Cd}, \mathrm{Pb}, \mathrm{Zn}$ and $\mathrm{Ni}$ concentrations in the leaves of urban deciduous trees in Istanbul. Environ Pollut 143:545-554 
Berlizov AN, Blum OB, Filby RH, Malyuk IA, Tryshyn VV (2007) Testing applicability of black poplar (Populus nigra L.) bark to heavy metal air pollution monitoring in urban and industrial regions. Sci Total Environ 372(2-3):693-706

Białońska D, Zobel A, Kuraś M, Tykarska T, Sawicka-Kapusta K (2007) Phenolic Compounds and Cell Structure in Bilberry Leaves Affected by Emissions from a $\mathrm{Zn}-\mathrm{Pb}$ Smelter. Water Air Soil Poll 181:123-133

Boojar MMA, Tavakkoli Z (2010) Role of antioxidant enzyme responses and phytochelatins in tolerance strategies of Alhagi camelorum Fisch growing on copper mine. Acta Bot Croat 69(1):107-121

Bothe H (2011) Plants in heavy metal soils. In: Sherameti I, Varma A (eds) Detoxification of heavy metals, soil biology 30. SpringerVerlag, Berlin Heidelberg, pp 35-56

Bradford M (1976) A rapid and sensitive method for the quantization of microgram quantities of protein utilizing the principle of protein dye binding. Anal Biochem 44:276-287

Chen CT, Chen TH, Lo KF, Chiu CHY (2004) Effects of proline on copper transport in rice seedlings under excess copper stress. Plant Sci 166(1):103-111

Chen B, Stein A, Castell N, Gonzalez-Castanedo Y, Sanchez de la Campa AM, de la Rosa JD (2016) Modeling and evaluation of urban pollution events of atmospheric heavy metals from large $\mathrm{Cu}$-smelter. Sci Total Environ 539:17-25

Chudzińska E, Diatta JB, Wojnicka-Półtorak A (2014) Adaptation strategies and referencing trial of Scots and black pine populations subjected to heavy metal pollution. Environ Sci Pollut Res 21(3):2165-2177

De Vos CHR, Vonk MJ, Vooijs R, Schat H (1992) Glutathione depletion due to copper-induced phytochelatin synthesis causes oxidative stress in Silene cucubalus. Plant Physiol 198:853-858

Divan AM, Oliveira PL, Perry CT, Atz VL, Azzarini-Rostirola LN, Raya-Rodriguez MT (2009) Using Wild Plant Species as Indicators for the Accumulation of Emissions from a Thermal Power Plant, Candiota, South Brazil. Ecol Indic 9:1156-1162

Doğanlar Z, Atmaca M (2011) Influence of Airborne Pollution on Cd, $\mathrm{Zn}, \mathrm{Pb}, \mathrm{Cu}$, and $\mathrm{Al}$ Accumulation and Physiological Parameters of Plant Leaves in Antakya (Turkey). Water Air Soil Poll 214(1/ 4):509-523

Dučić T, Maksimović V, Radotić K (2008) Oxalate oxidase and nonenzymatic compounds of the antioxidative system in young Serbian spruce plants exposed to cadmium stress. Arch Biol Sci Belgrade 60:67-76

El-Beltagi H, Mohamed AA (2010) Changes in nonprotein thiols, some antioxidant enzymes activity and ultrastructural alteration in radish plant (Raphanus sativus L.) grown under lead toxicity. Not Bot Hort Agrobot Cluj 38(3):76-85

Fang WC, Kao C (2000) Enhanced peroxidase activity in rice leaves in response to excess iron, copper and zinc. Plant Sci 158:71-76

Fonseca VF, França S, Serafim A, Company R, Lopes B, Bebianno MJ, Cabral HM (2011) Multi-biomarker responses to estuarine habitat contamination in three fish species: dicentrarchus labrax, Solea senegalensis and Pomatoschistus microps. Aquat Toxicol 102(3-4):216-227

Fowler D, Pilegaard K, Sutton MA, Ambus P, Raivonen M et al (2009) Atmospheric Composition Change: ecosystems-Atmosfere Interactions. Atmos Environ 43:5193-5267

Gill SS, Tuteja N (2010) Reactive oxygen species and antioxidant machinery in abiotic stress tolerance in crop plants. Plant Physiol Biochem 48:909-930

Gratão PL, Monteiro CC, Antunes AM, Peres LEP, Azevedo RA (2008) Acquired tolerance of tomato (Lycopersicon esculentum cv. Micro-Tom) plants to cadmium-induced stress. Ann Appl Biol 153:321-333
Hagemeyer J (2004) Ecophysiology of plant growth under heavy metal stress. In: Prasad MNV (ed) Heavy metal stress in plants: from biomolecules to ecosystems, 2nd edn. Springer, Berlin, pp 201-222

Ivanov YV, Savochkin YV, Kuznetsov VV (2012) Scots pine as a Model Plant for Studying the Mechanisms of Conifers Adaptation to Heavy Metal Action: 2. Functioning of Antioxidant Enzymes in Pine Seedlings under Chronic Zinc Action. Russ J Plant Physl 59(1):50-58

Ivanov YuV, Savochkin YuV, VlV Kuznetsov (2013) Development of scots pine seedlings and functioning of antioxidant systems under the chronic action of lead ions. Biol Bull 40(1):26-35

Kabata-Pendias A, Pendias H (2001) Trace Elements in Soils and plants third ed.CRC press, Boca Raton FL

Kafel A, Nadgórska-Socha A, Gospodarek J, Babczyńska A, Skowronek M, Kandziora M, Rozpendek K (2010) The effects of Aphis fabae infestation on the antioxidant response and heavy metal content in field grown Philadelphus coronarius plants. Sci Total Environ 408(5):1111-1119

Kandziora-Ciupa M, Ciepał R, Nadgórksa-Socha A, Barczyk G (2013) A comparative study of heavy metal accumulation and antioxidant responses in Vaccinium myrtillus L. leaves in polluted and non-polluted areas. Environ Sci Pollut Res 20(7):4920-4932

Kartashov AV, Radyukina NL, Ivanov YuV, Pashkovskii PP, Shevyakova NI, Kuznetsov VV (2008) Role of antioxidant systems in wild plant adaptation to salt stress. Russ J Plant Physiol 55(4):463-468

Kuang YW, Zhou GY, Wen DZ, Li J, Sun FF (2011) Analysis of polycyclic aromatic hydrocarbons in tree-rings of Masson pine (Pinus massoniana L.) from two industrial sites in the Pearl River Delta, South China. J Environ Monit 13:2630-2637

Kumar N, Pal M, Singh A, Kumar SaiRam R, Srivastava GH (2010) Exogenous proline alleviates oxidative stress vase life in rose (Rosa hybrida L. 'Grand Gala'). Sci Hortic 127:79-85

Lin R, Wang X, Luo Y, Du W, Guo H, Yin D (2007) Effect of soil cadmium on growth, oxidative stress and antioxidant system in wheat seedlings (Triticum aestivum L.). Chemosphere 69:89-98

Liu J, Xiong Z, Li T, Huang H (2004) Bioaccumulation and ecophysiological responses to copper stress in two populations of Rumex dentatus $\mathrm{L}$. from $\mathrm{Cu}$ contaminated and non-contaminated sites. Environ Exp Bot 52(1):43-51

Macfarlane GR, Burchett MD (2001) Photosynthetic pigments and peroxidase activity as indicators of heavy metal stress in the Grey Mangrove Avicennia marina (Forsk.) Veirh. Mar Pollut Bull 42:233-240

Madhava Rao KV, Sresty TVS (2000) Antioxidative parameters in the seedling of pigeonpea (Cajanus cajan L. Millspaugh) in response to $\mathrm{Zn}$ and Ni stresses. Plant Sci 157:113-128

Markkola AM, Tarvainen O, Ahonen-Jonnarth U, Strömmer R (2002) Urban polluted soils induce elevated root peroxidase activity in Scots pine (Pinus sylvestris L.) seedlings. Environ Pollut 116:273-278

Mass F, De Kok L, Peters J, Kuiper PA (1987) Comparative study on the effects of $\mathrm{H}_{2} \mathrm{~S}$ and $\mathrm{SO}_{2}$ fumigation on the growth and accumulation of sulfate and sulfhydryl compounds in Trifolium pratense L., Glycine max Merr., Phaseolus vulgaris L. J Exp Bot 38:1459-1469

Massa N, Andreucci F, Poli M, Aceto M, Barbato M, Berta G (2010) Screening for heavy metal accumulators amongst autochtonous plants in a polluted site in Italy. Ecotoxicol Environ Saf 73:1988-1997

McGee CJ, Fernandez IJ, Norton SA, Stubbs CS (2007) Cd, Ni, Pb, and $\mathrm{Zn}$ concentrations in forest vegetation and soils in Maine. Water Air Soil Pollut 180:141-153 
Mesmar MN, Jaber K (1991) The toxic effect of lead on seed germination, growth, chlorophyll and protein contents of wheat and lens. Acta Biol Hung 42(4):331-344

Mičieta K, Murín G (1998) Tree species of genus Pinus suitable as bioindicators of polluted environment. Water Air Soil Pollut 104:413-422

Mingorance MD, Valdés B, Rossini Oliva S (2007) Strategies of heavy metal uptake by plants growing under industrial emissions. Environ Int 33:514-520

Mishra S, Srivastava S, Tripathi RD, Kumar R, Seth CS, Gupta DK (2006) Lead detoxification by coontail (Ceratophyllum demersum L.) involves induction of phytochelatins and antioxidant system in response to its accumulation. Chemosphere 65:1027-1039

Mishra S, Tripathi RD, Srivastava S, Dwivedi S, Trivedi PK, Dhankher OP, Khare A (2009) Thiol metabolism play significant role during cadmium detoxification by Ceratophyllum demersum L. Bioresour Technol 100:2155-2161

Nadgórska-Socha A, Kafel A, Gospodarek J (2008) Heavy metals in leaves and physiological of Philadelphus coronarus L. in urban and unpolluted areas. Scripra Fac Nat Univ Ostrav 186:278-284

Nadgórska-Socha A, Kandziora-Ciupa M, Ciepał R (2011) Effects of $\mathrm{Zn}, \mathrm{Cd}, \mathrm{Pb}$ on physiological reponse of Silene vulgaris plants from selected populations. Pol J Environ Stud 20(3):599-604

Nadgórska-Socha A, Kafel A, Kandziora-Ciupa M, Gospodarek J, Zawisza-Raszka A (2013a) Accumulation of heavy metals and antioxidant responses in Vicia faba plants grown on monometallic contaminated soil. Environ Sci Pollut Res 20:1124-1134

Nadgórska-Socha A, Ptasiński B, Kita A (2013b) Heavy metal bioaccumulation and antioxidative responses in Cardaminopsis arenosa and Plantago lanceolata leaves from metalliferous and non-metalliferous sites: a field study. Ecotoxicology 22(9):14221434

Nieminen TM, Derome J, Saarsalmi A (2004) The applicability of needle chemistry for diagnosing heavy metal toxicity to trees. Water Air Soil Pollut 157(1-4):269-279

Nikolić N, Kojić D, Pilipović A, Pajević S, Krstić B, Borišev M, Orlović S (2008) Responses of hybrid poplar to cadmium stress: photosynthetic characteristics, cadmium and proline accumulation, and antioxidant enzyme activity. Acta Biol Cracov Ser Bot 502:95-103

Oliva M, José Vicente J, Gravato C, Guilhermino L, Dolores GalindoRiaño M (2012) Oxidative stress biomarkers in Senegal sole, Solea senegalensis, to assess the impact of heavy metal pollution in a Huelva estuary (SW Spain): seasonal and spatial variation. Ecotoxicol Environ Saf 75(1):151-162

Ots K, Mandre M (2012) Monitoring of heavy metals uptake and allocation in Pinus sylvestris organs in alkalised soil. Environ Monit Assess 184(7):4105-4117

Pacyna JM, Pacyna EG (2001) An assessment of global and regional emissions of trace metals to the atmosphere from anthropogenic sources worldwide. Environ Rev 9:269-298

Parzych A, Sobisz Z (2012) The macro- and microelemental content of Pinus sylvestris L. and Pinus nigra J.F. Arn. needles in Cladonio-Pinetum habitat of the Słowiński National Park. For Res Pap 73(4):295-303

Piczak K, Leśniewicz A, Żyrnicki W (2003) Metal concentrations in deciduous tree leaves from urban areas in Poland. Environ Monit Assess 86:273-287

Piechalak A, Tomaszewska B, Baralkiewicz D, Małecka A (2002) Accumulation and detoxification of lead ions in legumes. Phytochemistry 60:153-162

Pongrac P, Zhao FJ, Razinger J, Zrimec A, Regvar M (2009) Physiological responces to $\mathrm{Cd}$ and $\mathrm{Zn}$ in two $\mathrm{Cd} / \mathrm{Zn}$ hyperaccumulating Thlaspi species. Environ Exp Bot 66:479-486
Probst A, Liu H, Fanjul M, Liao B, Hollande E (2009) Response of Vicia faba L. to metal toxicity on mine tailing substrate: geochemical and morphological changes in leaf and root. Environ Exp Bot 66:297-308

Rademacher P (2001) Atmospheric Heavy Metals and Forest Ecosystems. Federal Research Centre for Forestry and Forest Products, BFH, Germany

Radotić K, Ducić T, Mutavdžic D (2000) Changes in peroxidase activity and isoenzymes in spruce needles after exposure to different concentrations of cadmium. Environ Exp Bot 44:105-113

Rautio P, Huttunen S, Lamppu J (1998) Seasonal foliar chemistry of northern Scots pine under sulphur and heavy metal pollution. Chemosphere 37(2):271-278

Sandalio LM, Dalurzo HC, Gómez M, Romero-Puertas MC, Del Río LA (2001) Cadmium-induced changes in the growth and oxidative metabolism of pea plants. $\mathrm{J} \operatorname{Exp}$ Bot 52(364):2115-2126

Sawidis T, Breuste J, Mitrovic M, Pavlovic P, Tsigaridas K (2011) Trees as bioindicator of heavy metal pollution in three European cities. Environ Pollut 159(12):3560-3570

Schat H, Sharma S, Vooijs R (1997) Heavy metal-induced accumulation of free proline in metal tolerant and nontolerant ecotype of Silene vulgaris. Physiol Plant 101:477-482

Schützendübel A, Schwanz P, Teichmann T, Gross K, LangenfeldHeyser R, Godbold DL, Polle A (2001) Cadmium-induced changes in antioxidative systems, hydrogen peroxide content and differentiation in Scots pine roots. Plant Physiol 127:887-892

Serbula SM, Kalinovic TS, Ilic AA, Kalinovic JV, Steharnik MM (2013) Assessment of airborne heavy metal pollution using Pinus spp. and Tilia spp. Aerosol Air Qual Res 13:563-573

Seregin I, Ivanov V (2001) Physiological aspects of cadmium and lead toxic effects on higher plants. Russ J Plant Physiol 48:523-544

Sharma SS, Dietz KJ (2006) The significance of amino acids and amino acid-derived molecules in plant responses and adaptation to heavy metal stress. J Exp Bot 57:711-726

Singh AK, Misra P, Tandon PK (2006) Phytotoxicity of chromium in paddy (Oryza sativa L.) plants. J Environ Biol 27(2):283-285

Słomka A, Libik-Konieczny M, Kuta E, Miszalski Z (2008) Metalliferous and non-metalliferous populations of Viola tricolor represent similar mode of antioxidative response. J Plant Physiol 165:1610-1619

Stobrawa K, Lorenc-Plucińska G (2007) Changes in antioxidant enzyme activity in the fine roots of black poplar (Populus nigra L.) and cottonwood (Populus deltoides Bartr. Ex Marsch) in heavy-metal-polluted environment. Plant Soil 298:57-68

Sudhakar S, Seema M, Rudra DT, Sanjay D, Dharmendra KG (2006) Coper-induced oxidative stress and responses of antioxidants and phytochelatins in Hydrilla verticillata (L.f.) Royle. Aquat Toxicol 80:405-415

Sun RL, Zhou QZ, Sun FH, Jin CX (2007) Antioxidative defense and proline/phytochelatin accumulationin a newly discovered Cdhyperaccumulator, Solanum nigrum L. Environ Exp Bot 60:468-476

Sun FF, da Wen Z, Kuang YW, Li J, Zhang JG (2009) Concentrations of sulphur and heavy metals in needles and rooting soils of Masson pine (Pinus massoniana L.) trees growing along an urban-rural gradient in Guangzhou, China. Environ Monit Assess 154:263-274

Sun F, Wen D, Kuang Y, Li J, Li J, Zuo W (2010) Concentrations of heavy metals and polycyclic aromatic hydrocarbons in needles of Masson pine (Pinus massoniana L.) growing nearby different industrial sources. J Environ Sci 22:1006-1013

Thomas DJ, Thomas JB, Prier SD, Nasso NE, Herbert SK (1999) Iron superoxide dismutase protects against chilling damage in the 
cyanobacterium Synechococcus species PCC7942. Plant Physiol 120:275-282

Tripathi BN, Gaur JP (2004) Relationship between copper- and zincinduced oxidative stress and proline accumulation in Scenedesmus sp. Planta 219:397-404

Yadav SK (2010) Heavy metals toxicity in plants: an overview on the role of glutathione and phytochelatins in heavy metal stress tolerance of plants. S Afr J Bot 76:167-179
Zengin FK, Munzuroglu O (2005) Effects of some heavy metals on content of chlorophyll, proline and some antioxidant chemical. Acta Biol Crac Ser Bot 47:157-164

Zhao H, Shao Y, Yin Ch, Jiang Y, Li X (2016) An index for estimating the potential metal pollution contribution to atmospheric particulate matter from road dust. Sci Total Environ 550:167-175 